\title{
LOST IN THE PROCESS: HOW STAKEHOLDERS VIEW THE QUALITY OF PUBLIC UNIVERSITIES IN CROATIA?
}

Irena PETRUŠı́́

Agency for Science and Higher Education, Zagreb

UDK: 378.014.6(497.5)

Izvorni znanstveni rad

Primljeno: 15. 1. 2018.

Outcome-based education is becoming relevant discourse in evaluating the quality of study programmes through the European Commission Policies. Using an analysis of the evaluation indicators that point to the desired concept of quality, this research provides a deeper insight into the expectations that the major stakeholders (government, academia and agencies) in the Croatian higher education system have from public universities and whether these institutions are output-oriented, which is stated as an objective in the European, and also in the Croatian context. The perception of quality that stakeholders imply by measuring the academic performance of public universities for different purposes is analysed by means of characteristics of indicators in the input-process-output matrix. The results show that the overall quality is largely based on measuring the quality of processes at higher education institutions, then on inputs and very little on outputs. According to the importance of indicators, teacher and student mobility are categories evaluated in the documents of all stakeholders. Lastly, this study contributes to the consideration and evaluation of the quality of public universities at the national level and their compatibility with international perspectives.

Keywords: academic quality, public university, input-process-output matrix

Irena Petrušić, Agency for Science and Higher Education, Donje Svetice 38/5, 10000 Zagreb, Croatia. 
The importance of academic quality is featured in the documents which, on the European level, regulate the question of quality assurance in higher education (ENQA, 2015). In the systems of quality assurance, the stakeholders have an indisputable role.

Considering the quality of education from their own perspective, stakeholders develop a variety of external quality evaluation systems in order to capture, evaluate and present the quality of the institution. In higher education, quality is an ambivalent and value-burdened term (Harvey \& Green, 1993; Maguire \& Gibbs, 2013) and therefore sought to be more precisely defined through its evaluation procedures. Due to this reason, the concept of quality that is promoted through valuation should be analysed and defined with regard to stakeholders in the system of higher education and science, meaning: potential students, students, institutions, employees at higher education institutions, employers and financers (Blanco-Ramírez \& Berger, 2014; Choy \& Lidstone, 2011; Urbanovič \& Wilkins, 2013).

Defining and analysing instruments, primarily evaluation, which are used to implement quality policies in higher education, occur in most cases in parallel with the attempt to define them (Van Vught \& Westerheijden, 1994). The models of external evaluation of the quality of higher education institutions consist of indicators measuring the input, the process and the output. The choice of indicators is based on the specifics of the national system, the quality model and, ultimately, on the availability of information (Chalmers, 2008; Killen, 2000), depending on the agent and objectives to be achieved. This clearly links the quality assurance procedures with the desired results of the quality assurance policy.

The reference literature which was used as a starting point for this research includes (Harvey \& Green, 1993) dimensions that define that academic quality through its characteristics: quality as excellence, quality in accordance with standards, quality as a fit of purpose, quality as being important financially and quality as a transformation. All these categories of quality include a wide spectrum of various interpretations, featuring its relevant characteristics and the basics which can be defined through its goals. Alongside the research framework that defines quality, the focus of the work is on the actual aspects of valuation and goals of the procedures of external quality assurance (Filippakou, 2011; Harvey \& Newton, 2004; Van Kemenade, Pupius, \& Hardjono, 2008).

Maguire and Gibbs (2013) recommend a theoretical framework for describing quality that positions quality as a "lens of truth" in various theoretical directions: the correspondence 
DRUŠ. ISTRAŽ. ZAGREB GOD. 28 (2019), BR. 2, STR. 333-352

PETRUŠIĆ, I.: LOST IN THE PROCESS.. theory, the coherence theory, the pragmatic theory, the constructive theory and the consensus theory. The perspective for this research represents a pragmatic theory which highlights the utilitarian picture and the definition of quality, especially through the "fit for purpose" approach.

In systems where the goals of the policies of quality are clearly highlighted, they are evident in the results that they want to achieve through the methods themselves. In contrast, in systems where these goals are not pre-defined, clear to all stakeholders and evident in the procedures of external evaluation of quality in higher education, the area becomes open for possible disadvantages, overlapping and misinterpretation.

Given that there are no single nor common policy objectives of academic quality, apart from the declarative level, the aim of this research is to map the dimensions of the quality of public universities in Croatia as perceived by stakeholders. Based on the comparison of the quality indicators in public universities' evaluations carried out by three major stakeholders, this study is focusing on the following questions: Are there any discrepancies or overlapping in the quality evaluations of public universities? Are they output-oriented, which is an objective in the European, but also in the Croatian context?

\section{THE QUALITY ASSURANCE CONTEXT IN EUROPE AND CROATIA}

In the European context, quality evaluation in higher education is linked to its massification and has had a propulsive expansion in the last twenty years. Higher education becomes more heterogeneous in terms of the diversity of institutions, students and teachers, changes in the relationship between higher education institutions and state administration bodies (from the model of state control to the model of state supervision), the increasing role of market regulation, increased institutional autonomy and the lack of trust in universities (de Sousa Santos, 2006). At first, external evaluation has the role of a mechanism for securing minimum academic quality (accreditation), and after some time, only the role of accreditation in the evaluation is lost and various tools are introduced to improve the institutions' performance. Their starting point is financing and sometimes, the comparison of the performance of the institutions.

With the development of competitive ranking systems, the role of external valuation of institutions and programmes is changing - the effects of institutions are increasingly quantified and compared, and the impact of the procedures and measures is valorised (Tavares, Sin, Videira, \& Amaral, 2016). From this perspective, the institutions are exposed to an increasing amount of valuation in order to demonstrate their public responsibility and on the other hand, they question the real ef- 
DRUŠ. ISTRAŽ. ZAGREB GOD. 28 (2019), BR. 2, STR. 333-352

PETRUŠIĆ, I.: LOST IN THE PROCESS.. fects of these procedures on improving quality at an institutional and systemic level (Stensaker \& Leiber, 2015).

Focusing on the performance of institutions is becoming more and more the discourse in evaluating the quality of study programmes, amongst other things, and through the European Commissions' policies (Stensaker \& Leiber, 2015). This is evident from the increasing role of qualifications frameworks and attention to learning outcomes expressed at the European level (Beerkens, 2015).

The outcome-based approach is based on measuring educational effectiveness in terms of the time spent and the student achievements, as outcomes which are the difference in society made by the outputs. Outcomes are not specifically measured in the Croatian higher education system and in this study, we focus on outputs, as their existence is a prerequisite for effective outcomes. Outputs as units of analysis are trying to capture what is really important and also place a focus on the results of the process that are not burdened with the mechanisms of the process itself. When further elaborating the reflexions of the outcome-based approach in Croatian higher education, it is important to highlight the context of the size of the education system in which it is taking place. According to its structure, Croatian higher education is binary and encompasses university and professional studies. It comprises slightly less than 1,300 study programmes, most of them university study programmes, in $81 \%$ of cases performed at public universities. ${ }^{1}$ The number of students in the higher education system is around 195,000 students. Comparing to the other European higher education systems, the Croatian system is small, heterogeneous and rather centralised. It includes 125 higher education institutions -8 public universities, 2 private universities, 67 faculties and academies, 3 private polytechnics, 12 public polytechnics, 23 private colleges and 3 public colleges.

The quality assurance system began as an element of European integration, but it has outgrown that framework and has become a mechanism for assessing the accountability of the public higher education institutions. The shift of quality assessment as a tool for improvement, noted in Croatia in the period 2003-2009 through the establishment of a national accreditation authority, the Agency for Science and Higher Education (ASHE), whose evaluations explicitly follow the European Standards and Guidelines (ESG) and has been registered on the EQAR since 2011, followed the revision of the former system for external assessment of the quality of programmes and institutions. In that period, the quality assurance system was concerned with ensuring minimum conditions with a strong emphasis on input indicators (number and rank of teachers in the study programmes) and the process (do- 
DRUŠ. ISTRAŽ. ZAGREB GOD. 28 (2019), BR. 2, STR. 333-352

PETRUŠIĆ, I.: LOST IN THE PROCESS.. cumentation and internal quality assurance systems), however, the government directs quality assurance policies through a strategic shift in higher education and science based on output indicators.

The current quality assurance framework consists of:

a) internal quality assurance procedures and practices through which academic institutions control and improve the quality of their activities,

b) an external and independent periodic assessment that is primarily focused on the institutional strengthening of the capacities of higher education institutions,

c) accreditation for starting a higher education programme and/or an institution,

d) re-accreditation as a dominant process of evaluation and assessment of the quality of existing programmes and institutions,

e) the thematic evaluation aimed at reviewing the state of the system of higher education with regard to the specific topic to be examined.

The procedures for external assessment of the quality of higher education institutions are compulsory for all higher education institutions in Croatia and are conducted by the national agency, the Agency for Science and Higher Education (ASHE).

In the relatively new system of quality assurance, along with the existence of clear and transparent procedures for external evaluation and the publication of their results, the goals of these procedures remain unclear and are differently understood by the stakeholders. It is quite understandable that all stakeholders do not have the same goals and expectations of the external valuation procedures that they carry out, but the deviations in their claimed goals provide a further warning alongside the quality indicators in the valuation tools that are supposed to achieve them. To the best of our knowledge, such an analysis of the quality perception of the higher education system by different stakeholders on a national level, is not performed by other members of the EU. The reason behind this might be the size and the complexity of the higher education system which, in contrast to the Croatian centralised system of quality control, does not allow for exact comparison amongst the stakeholders. The only exemption is the research of Udam and Heidmets (2013), whose results are quite different from ours.

Finally, a possible common starting point for its harmonisation with this internationally up-to-date European trend will be presented. This policy debate aims to highlight policymakers, all stakeholders and the need to set clear objectives of quality policies in higher education as well as contribute to its synchronisation. 
In Croatia, in addition to the formal quality assurance system (stipulated by the Law on Quality Assurance in Science and Higher Education (OG 45/09)), there are other forms of external evaluation of higher education institutions and scientific institutes covered by regulatory documents, for different purposes - for example, to determine the status of an institution or its government funding, elections, etc. The results of these evaluations directly affect the quality of public universities and institutions and/or the programme development.

The engagement of stakeholders is presented through Clark's model (Clark, 1983), which is based on the relationship between the three major stakeholders - academia, government and the market (represented by quality assurance agencies). These are the stakeholders who have the most important roles in the quality assurance policies:

The government - this includes government, ministries and local government, and in this specific case, represents the ministry and parliamentary body (national council) responsible for higher education and science.

The academy - representatives of the academic community - professors, lecturers, deans, heads, institute directors, other heads of institutions and quality assurance units.

The agency - the agency is independent of government administration and university autonomy (Santiago \& Carvalho, 2012). The government agencies, in the Croatian context, represent end-users (students and parents) in negotiations with competitive higher education providers (Rosa \& Amaral, 2007), especially in higher education systems that resemble quasimarkets (Santiago \& Carvalho, 2012).

The first set of data consists of documents that are defined by the government for the different needs of the institution or programme quality evaluation in order to regulate their status. The second set consists of documents published by public universities in order to improve their own quality. The third set of data refers to documents whose purpose is to directly "measure" the quality of higher education institutions, provided by the quality assurance agency.

For the purpose of the analysis and comparison of all three sets of data, a qualitative document analysis method was used (Cohen, Manion, \& Morrison, 2007) based on text coding (Bowen, 2006). In the field of higher education research, this methodology represents one of the three most commonly used methods, as derived from Tight's (Tight, 2013) analysis of the methodological frameworks in the field of higher education research as a multidisciplinary field.

The results of their comparisons will be discussed through the "fit for purpose" theoretical approach, presented as an in- 
tegral part of Harvey's Analytical Framework (Harvey, 2006) of the relationship between quality and standard.

\begin{tabular}{|c|c|c|}
\hline Government & Academia & Quality assurance agency \\
\hline $\begin{array}{l}\text { The Strategy of } \\
\text { Education, Science and } \\
\text { Technology (CP, 2014) }\end{array}$ & $\begin{array}{l}\text { Ordinance on the } \\
\text { Conditions of Academic } \\
\text { Appointment (NSC, 2007) }\end{array}$ & $\begin{array}{l}\text { Principles and Criteria for } \\
\text { the Evaluation of } \\
\text { Scientific Organizations } \\
\text { in the Republic of Croatia } \\
\text { (ASHE, 2013) }\end{array}$ \\
\hline $\begin{array}{l}\text { Multi-Annual Institutional Fund- } \\
\text { ing of Scientific Activities at Public } \\
\text { Universities and Research } \\
\text { Institutions in 2013, } 2014 \text { and } \\
2015 \text { (MSE, 2013) }\end{array}$ & $\begin{array}{l}\text { Quality Assurance Hand- } \\
\text { books for each of the } 7 \text { pub- } \\
\text { lic universities (Osijek,2 } \\
\text { Pula, }{ }^{3} \text { Dubrovnik, }{ }^{4} \text { Rijeka, } \\
\text { Split, }{ }^{6} \text { Zadar, }{ }^{7} \text { Zagreb }{ }^{8} \text { ) }\end{array}$ & $\begin{array}{l}\text { Principles and Criteria } \\
\text { for the Evaluation of } \\
\text { Postgraduate University } \\
\text { Studies in the Republic } \\
\text { of Croatia (ASHE, 2015) }\end{array}$ \\
\hline $\begin{array}{l}\text { Ordinance on the Content } \\
\text { of License and Conditions } \\
\text { for Issuing License for Performing } \\
\text { Higher Education Activity, } \\
\text { carrying out a Study } \\
\text { Programme and Re-accreditation of } \\
\text { Higher Education Institutions } \\
\text { (MSE, 2010a) }\end{array}$ & & $\begin{array}{l}\text { Criteria for the Quality } \\
\text { of Higher Education } \\
\text { Institutions within } \\
\text { Universities (ASHE, 2010) }\end{array}$ \\
\hline $\begin{array}{l}\text { Ordinance on Conditions for Issuing } \\
\text { License for Scientific Activity, } \\
\text { Conditions for Re-accreditation of } \\
\text { Scientific Organisations and Content } \\
\text { of License (MSE, 2010b) }\end{array}$ & & \\
\hline $\begin{array}{l}\text { Decisions on grants for study costs } \\
\text { for full-time first-year students at } \\
\text { public higher education institutions } \\
\text { in the Republic of Croatia (MSE, 2012) }\end{array}$ & & \\
\hline
\end{tabular}

(1) TABLE 1 Sample - documents taken into analysis according to stakeholders
Ordinance on the

Conditions of Academic

Appointment (NSC, 2007)

Quality Assurance Handbooks for each of the 7 public universities (Osijek, ${ }^{2}$ Pula, ${ }^{3}$ Dubrovnik, ${ }^{4}$ Rijeka, Split, ${ }^{6}$ Zadar, $^{7}$ Zagreb $^{8}$ )

\author{
Principles and Criteria for \\ the Evaluation of \\ Scientific Organizations \\ in the Republic of Croatia \\ (ASHE, 2013) \\ Principles and Criteria
for the Evaluation of
Postgraduate University
Studies in the Republic
of Croatia (ASHE, 2015)
Criteria for the Quality
of Higher Education
Institutions within
Universities (ASHE, 2010)
}

The contents of the indicators within these two samples are coded by the researcher assigning them a numerical value (Elo \& Kyngäs, 2008) to facilitate operationalisation. The indicators used in these sets of data - strategic documents and evaluations carried out within the framework of the existing quality assurance system are coded according to the content and in relation to the input-process-output indicator matrix (Chalmers, 2008; Ghurchian, Jafari, \& Rahgozar, 2010; Udam \& Heidmets, 2013).

The content of each individual document is analysed by reference to the orientation of the content of the indicator according to the matrix: input- process- output in Table 2. If there is an index of contents that are relevant to one of the groups within the given matrices, the indicator gains value 1 , and if this correlation link does not exist, then the value 0 is assigned. 


\begin{tabular}{|c|c|c|}
\hline Input & Process & Output \\
\hline $\begin{array}{l}\text { The number and } \\
\text { qualifications of teachers }\end{array}$ & $\begin{array}{l}\text { Institution functioning } \\
\text { (i.e. mission statements, } \\
\text { strategic plans, action } \\
\text { plans, internal policies, etc.) }\end{array}$ & $\begin{array}{l}\text { Completion / drop-out } \\
\text { rate }\end{array}$ \\
\hline Enrolment requirements & $\begin{array}{l}\text { Teaching process and } \\
\text { interaction of participants } \\
\text { in these processes }\end{array}$ & Graduation time \\
\hline Teacher-student ratio & $\begin{array}{l}\text { Students' / teachers' } \\
\text { workload for different } \\
\text { teaching units or for } \\
\text { different forms of work } \\
\text { (lectures, seminars, etc.) }\end{array}$ & $\begin{array}{l}\text { Employment rate (in the } \\
\text { relevant business sector) }\end{array}$ \\
\hline Resources & $\begin{array}{l}\text { ECTS per study course or } \\
\text { study programme }\end{array}$ & Number of graduates \\
\hline Premises (per student) & Student survey on teaching & Publications \\
\hline Curricula & Alumni feedback & University reputation \\
\hline \multicolumn{3}{|l|}{ Planned student qualifications } \\
\hline Material and financial resources & & \\
\hline
\end{tabular}

(D) TABLE 2

Quality indicators classified with regard to the input-process-output matrix adapted according to Van Damme, Van Der Hijden, \& Campbell, 2004; Blanco-Ramírez \& Berger, 2014
The "not applicable" mark is for those indicators that are not relevant to the quality evaluation of the institution and the study programme. The most common are the measures that need to be implemented at the national higher education level and cannot be used to evaluate the quality of an individual study programme or higher education institution.

The value of 1 input data is allocated if the indicators within the mentioned document value student, teaching and financial resources. Process 1 is assigned value 1 if the evaluation indicators within the analysed document are relevant to the functioning of the institution, the teaching process, and the interaction of participants in these processes. Value 1 is assigned to outputs for those indicators that relate to short-term and long-term results, such as the number of graduates, scientific publications, and similar (Table 2).

The coding table for sample analysis is composed by categorising the valuation indicators with regard to their content orientation, to one of the groups within the input-process-output indicator matrix (Table 2).

Finally, we compared the weighted average of each input, process and output indicators for each of the analysed stakeholder groups. Given that this is a very heterogeneous group of documents, with a different number of indicators, the percentages in their total number are taken into account. 


\section{Methodological constraints}

This method is based on indirect researchers' observations of the documents and the lack of interaction between the researchers in writing, which reduces bias and subjectivity. Subjectivity has been further mitigated by a predetermined and solid analytical framework (matrix) as well as the inability of researchers to influence the authors of analysed documents. Reliability was sought from the size of the sample - although it is a relatively small number of documents, all documents in the national higher education system are represented, which indirectly and directly measure and value the quality of public universities.

The limitations of this study relate to the representation of the components and programmes of public universities in the sample, as the research did not include other higher education institutions in the system (private universities, private and public polytechnics and colleges). According to the percentage of students, teachers and study programmes in the total number, about $17 \%$ of the system is not affected by this research.

\section{RESULTS AND DISCUSSION}

\section{Government regulatory framework}

The Strategy of Education, Science and Technology of the Government of the Republic of Croatia (CP, 2014) which, apart from the majority of the guidelines, also contains indicators of its implementation. A text section that does not include quality indicators was not subject to content analysis. Through that document, it declaratively promotes the quality enhancement the of higher education and science systems, mainly based

(1) TABLE 3

Number of indicators (and percentage) in regulatory documents according to the input-process-output matrix on student competencies and the quality of the staff structure, however, most of the cases refer to the processes (30 indicators) and evaluation of activities at higher education institutions and scientific institutions (Table 3).

Government regulatory documents Input

Process

Output

The Strategy of Education, Science and Technology

of the Government of the Republic of Croatia (CP, 2014)

$18(0.35) \quad 30(0.58) \quad 4(0.08)$

Programme agreements - higher education

institutions (MSE, 2012)

$3(0.21) \quad 9(0.64) \quad 2(0.14)$

Programme agreements - scientific institutions (MSE, 2013)

Minimum conditions (MSE, 2010a)

$1(0.17)$

$1(0.17)$

$4(0.67)$

$6(1)$

$0(0)$

Sum (weighted average)

$28(0.36) \quad 40(0.51) \quad 10(0.13)$


DRUŠ. ISTRAŽ. ZAGREB GOD. 28 (2019), BR. 2, STR. 333-352

PETRUŠIĆ, I.: LOST IN THE PROCESS..
The analysis of the indicators was performed according to general and specific objectives, and the encoding constraint makes it impossible to classify the non-applicable implementation indicators in the input-process-output matrix (Table 2). The performance indicators of the higher education institution for its funding significantly give weight to processes (9, or $64 \%)$, the input data $(3$, or $21 \%)$ and the output $(2$, or $14 \%)$. Although the institutions of higher education have chosen the indicators to be used, this analysis has included all the indicators and shows that the most prominent area in which the institution's performance is measured is its functioning and its internal organisation that is presented through process indicators.

Indicators of long-term institutional funding have different weight ratios (ranging from 5 , or $60 \%$ ) but are unique in their content orientation, primarily on the output (4, or $67 \%)$. The evaluation system for financial allocation for scientific activity is the only output-oriented policy document. This type of evaluation system is uniquely focused on the indicators of scientific production as the dominant indicators of the quality of scientific institutions, including universities that are engaged in scientific activity.

The minimum requirements for higher education activities, just like the procedures covered by the legal framework whose purpose is to ensure quality, relate only to the evaluation of the input data (inputs) (6 or 100\%) for the purpose of providing good prerequisites for the study programme or the functioning of higher education institutions.

Looking at the policy documents cumulatively, from the aspect of distributing individual indicators through the input-process-output matrix, their dispersion revealed a poor focus on the balance of input, process and output indicators. Although some of the documents are weighted by input (Minimum Conditions for Higher Education and Science and Technology Strategy), or outputs (Programme Contracts - Science, Criteria for Evaluating Scientific Organisations and Rulebooks for selection in scientific titles), each of the analysed documents encompasses the process evaluation. A prominent process (with more than 50\%) evaluates strategic documents and documents relevant to the allocation of financial resources to public universities.

The shift in education whose quality is perceived through the process and input towards output-based education, the aims of which are contained in policy documents and legal solutions, is not adequately reflected through the indicators of the evaluation and promotion of output quality within the existing (analysed) documents. 


\section{Documents published by the academia}

This set of analysed data comprises performance indicators developed by the universities in order to track their own performance. In most analysed cases, they are contained in two different documents - the Quality Assurance Handbook, which facilitates the evaluation of the internal quality assurance system, and the criteria adopted by public universities for self-accreditation of study programmes.

$\rightarrow$ TABLE 4

Number of indicators (and percentage) in academia documents according to the input-process-output matrix

\begin{tabular}{lrrr}
\hline Academia & Input & Process & Output \\
\hline University of Zagreb & $14(0.45)$ & $12(0.39)$ & $5(0.16)$ \\
University of Dubrovnik & $3(0.07)$ & $34(0.81)$ & $5(0.12)$ \\
University of Split & $6(0.27)$ & $12(0.55)$ & $4(0.18)$ \\
University of Osijek & $4(0.14)$ & $19(0.66)$ & $6(0.21)$ \\
University of Pula & $5(0.19)$ & $13(0.48)$ & $9(0.33)$ \\
University of Rijeka & $2(0.09)$ & $15(0.68)$ & $5(0.23)$ \\
University of Zadar & $6(0.13)$ & $33(0.70)$ & $8(0.17)$ \\
Sum (weighed average) & $40(0.26)$ & $138(0.66)$ & $42(0.21)$ \\
\hline
\end{tabular}

The most significant percentages of input indicators are found in the documents of the University of Zagreb (0.45) and the University of Split (0.27). The highest percentage of output indicators belong to the University of Pula (0.33) and the University of Rijeka (0.23) (Table 4).

The focus of the academia's evaluation is the process (the total number of indicators is 138, with an average percentage of 66). The number of these indicators is almost three times higher than the input (40) and output (42) indicators. The weighted average of output is slightly higher $(0.28)$ than the input indicator (0.26) (Table 4).

The public universities themselves evaluate their quality based on the quality of the process, and their processes are based on indicators that directly influence the evaluation and improvement of activities that are taking place there - teaching and learning, societal roles, and to a lesser extent the research process. It seems that, by regulating and measuring improvements within their own quality system, public universities are trying to raise their level of quality, however, such a qualitative approach to quality assessment could ultimately result in a high amount of administrative burden on staff and teachers.

\section{Principles and criteria for the assessment of the quality of the institution and/or programme (Agency as a regulator) in the external quality assurance procedures}

According to the input-process-output matrix (Table 2), 6 indicators (55\%) within the documents for evaluation of public scientific institutes are directed to output (scientific production), while the least of them involve the process $(2$, or $18 \%)$. 
DRUŠ. ISTRAŽ. ZAGREB

GOD. 28 (2019), BR. 2, STR. 333-352

PETRUŠIĆ, I.:

LOST IN THE PROCESS..
The distribution of indicators in Table 5 shows that the indicators of the process categories have the highest percentage in the overall quality assessment of the doctoral programmes performed at universities $(27$, or $79 \%)$. They include teaching processes and institutional quality improvement mechanisms. The output indicators for the evaluation of doctoral studies are represented in only 3 indicators.

\begin{tabular}{lrrr}
\hline Quality assurance procedures (Agency) & Input & Process & Output \\
\hline $\begin{array}{l}\text { Principles and Criteria for the Evaluation of Scientific } \\
\text { Organisations in the Republic of Croatia }\end{array}$ & $3(0.27)$ & $2(0.18)$ & $6(0.55)$ \\
$\begin{array}{l}\text { Principles and Criteria for the Evaluation of Postgraduate } \\
\text { University Studies in the Republic of Croatia }\end{array}$ & $4(0.12)$ & $27(0.79)$ & $3(0.09)$ \\
$\begin{array}{l}\text { Criteria for the Quality of Higher Education } \\
\text { Institutions within Universities }\end{array}$ & $15(0.29)$ & $27(0.53)$ & $9(0.18)$ \\
Quality Audit & $2(0.25)$ & $6(0.75)$ & $0(0)$ \\
Sum (weighted average) & $24(0.26)$ & $62(0.65)$ & $18(0.28)$
\end{tabular}

(1) TABLE 5

Number of indicators (and percentages) in the principles and criteria for the assessment of the quality of the institution and/or programme in the external quality assurance procedures according to the input-process-output matrix
Documents containing the quality assessment indicators have based the decision that is made on the quality of a higher education institution and its programmes. The ratio of quality indicators in these documents has been almost constant over the years and is based on the process of quality assessment that makes it the highest percentage in quality assurance $(27$, or $53 \%)$. The input $(15$, or $29 \%)$ ratio is slightly greater than the output $(9$, or $18 \%$ ).

The quality assurance approach that is implemented by the Agency is largely based on the monitoring and evaluation of process indicators. This approach is based on checking the existence and functioning of mechanisms for evaluating and improving the quality of the research and teaching process. Evaluating the quality of outputs that teachers and students achieve through research and teaching processes, is currently not sufficiently represented as an incentive for higher education institutions to achieve results that are visible in the international context.

In the documents of different stakeholders, the results show that the perceptions and measurements of public university quality are similar. From the viewpoint of the government, quality is largely represented by processes at higher education institutions $(15$, or $51 \%)$, then by inputs $(7$, or $36 \%)$, and very little by outputs $(2.5$, or $13 \%)$. These indicators are aimed at regulating the field of higher education through the impact on the processes within them.

Public universities perceive their quality through evaluation of the process $(10$, or $66 \%)$, however, a little advantage is given to the number of output indicators $(3.13$, or $21 \%$ ) compared to the input indicators $(2.56$, or $26 \%)$. 
DRUŠ. ISTRAŽ. ZAGREB GOD. 28 (2019), BR. 2, STR. 333-352

PETRUŠIĆ, I.: LOST IN THE PROCESS..

\section{$\rightarrow$ FIGURE 1}

Distribution of indicators in the regulatory documents of all stakeholders according to the input-process-output matrix

The external evaluations carried out by the quality assurance agency are strongly focused on the process $(15,50$, or $65 \%)$, input $(6$, or $26 \%)$, and ultimately the output $(4.50$, or $28 \%)$.

Comparison of the indicators of all stakeholders (differences and overlapping)

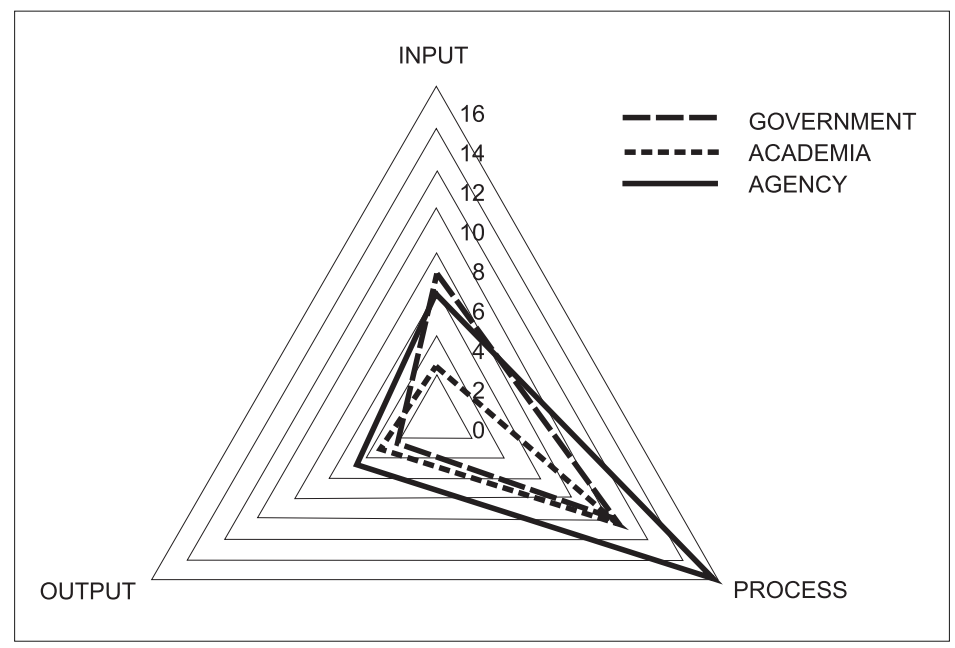

\section{FIGURE 2}

Distribution of indicators (percentages) in the regulatory documents of all stakeholders according to the input-process-output matrix

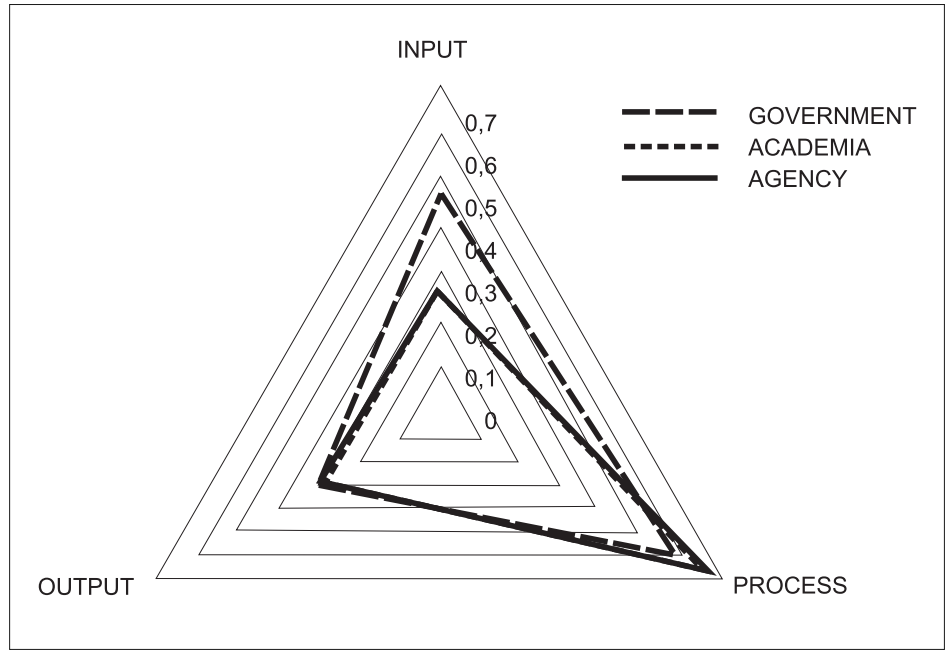

The results in Table 6 show a marked overlap in the indicators' content ranging in average from 3.33 to 4.67. According to the importance of indicators, teacher and student mobility are categories evaluated in the documents of all stakeholders. Strategic plans and their elaboration are also of the highest importance (4.33), as well as some of the input indicators (number and qualifications of researchers and terms of enrolment in the higher education institution). 
Input-

Government Agency Academia -Process-Output Average Sum

\begin{tabular}{|c|c|c|c|c|c|c|}
\hline Student mobility & 3 & 7 & 4 & $\mathrm{P}$ & 4,67 & 14 \\
\hline Teacher mobility & 3 & 7 & 4 & $\mathrm{P}$ & 4,67 & 14 \\
\hline \multicolumn{7}{|l|}{ Strategic documents, } \\
\hline organisational structure & 2 & 7 & 4 & $\mathrm{P}$ & 4,33 & 13 \\
\hline Enrolment prerequisites & 2 & 8 & 3 & I & 4,33 & 13 \\
\hline Student support & 2 & 8 & 3 & $\mathrm{P}$ & 4,33 & 13 \\
\hline Employment rate & 2 & 8 & 3 & $\mathrm{O}$ & 4,33 & 13 \\
\hline Number of researchers & 2 & 7 & 4 & I & 4,33 & 13 \\
\hline Qualification of researchers & 2 & 7 & 4 & $\mathrm{I}$ & 4,33 & 13 \\
\hline Ádequate number of publications & 2 & 7 & 4 & $\mathrm{O}$ & 4,33 & 13 \\
\hline Equipment & 2 & 7 & 4 & I & 4,33 & 13 \\
\hline Financial sustainability & 2 & 7 & 4 & $\mathrm{P}$ & 4,33 & 13 \\
\hline \multicolumn{7}{|l|}{ Monitoring of teaching and } \\
\hline research mechanisms & 2 & 7 & 3 & $\mathrm{P}$ & 4,00 & 12 \\
\hline Enrolment quota & 1 & 8 & 3 & I & 4,00 & 12 \\
\hline Graduate learning outcomes & 1 & 8 & 3 & $\mathrm{O}$ & 4,00 & 12 \\
\hline Assessment & 1 & 8 & 3 & $\mathrm{P}$ & 4,00 & 12 \\
\hline Efficient feedback mechanisms & 2 & 7 & 3 & $\mathrm{P}$ & 4,00 & 12 \\
\hline \multicolumn{6}{|l|}{ Teaching workload monitoring } & 12 \\
\hline \multicolumn{7}{|l|}{ The strategy of scientific research } \\
\hline Adequate number of scientific projects & 1 & 7 & 4 & $\mathrm{O}$ & 4,00 & 12 \\
\hline Technology transfer & 1 & 7 & 4 & $\mathrm{O}$ & 4,00 & 12 \\
\hline \multicolumn{7}{|l|}{ Mechanisms for attracting student } \\
\hline Physical resources & 2 & 7 & 3 & I & 4,00 & 12 \\
\hline Institutional mission & 0 & 7 & 4 & I & 3,67 & 11 \\
\hline Academic integrity procedures & 0 & 7 & 4 & $\mathrm{P}$ & 3,67 & 11 \\
\hline \multicolumn{7}{|l|}{ Study programme monitoring } \\
\hline mechanisms & 1 & 7 & 3 & $\mathrm{P}$ & 3,67 & 11 \\
\hline Learning support mechanisms & 1 & 7 & 3 & $\mathrm{P}$ & 3,67 & 11 \\
\hline Number of teachers & 1 & 7 & 3 & I & 3,67 & 11 \\
\hline Teacher qualifications & 1 & 7 & 3 & I & 3,67 & 11 \\
\hline \multicolumn{7}{|l|}{ Research workload monitoring } \\
\hline Non-teaching staff development support & 1 & 7 & 3 & $\mathrm{P}$ & 3,67 & 11 \\
\hline Teacher-student ratio & 0 & 7 & 3 & I & 3,33 & 10 \\
\hline
\end{tabular}

o TABLE 6

The frequency of indicators represented in all analysed documents
The output indicators that are of high importance are the employability rate of graduate students (4.33), the number of scientific publications (4.33), learning outcomes of graduate students (4.00) and transfer of technology (4.00).

Most of the process performance indicators are related to the quality of student experience and tracking their progress (i.e. student support, teaching and research monitoring mechanisms, procedures for monitoring the quality of study programmes, physical resources and teaching aids, etc.).

The indicators of the process that are represented by frequency in all the analysed evaluations show the importance of their measurement in all evaluations. They are of a quantitative nature and are therefore easier to measure and present. 
DRUŠ. ISTRAŽ. ZAGREB GOD. 28 (2019), BR. 2, STR. 333-352

PETRUŠIĆ, I.: LOST IN THE PROCESS..
The output indicators, although small in number, are represented in all the evaluations.

The government, to a greater extent than other stakeholders, by controlling the input (number and qualifications of teachers and physical resources) is trying to influence the quality of education. However, putting the focus on the processes and activities that take place at public universities for the purpose of granting financial resources results in a misbalance in relation to other activities related to the threefold role of public universities in society (teaching and learning, scientific activity and societal role).

On the other hand, efforts related to outcome-based education are seen in the frequency analysis of the occurrence of outcome-related indicators. Although few, the outcome indicators are represented in all the evaluations (Table 6).

If state-based evaluation systems want to encourage the development of outcome-based education, additional efforts should be made to ensure that the indicators that measure the quality of a higher education institution and programme are focused on what they want to achieve by using these models. These are primarily the higher outputs of the educational and research process. Likewise, in order to stimulate better quality of the scientific component of higher education, quality assessment should include a higher percentage of outputs.

In the existing quality assurance framework, although declaratively seeking to evaluate the quality through the output, the output indicators occupy a relatively small part of the spectrum of the stakeholders' interest. The potential reasons for such a misbalance could be found in the academic quality evaluation system which is traditionally focused on the number and qualifications of teachers (input), emphasising only the basic assurance of the quality of the teaching process, and also in the inadequate experience regarding the evaluation of academic quality through output indicators.

Returning to the aim of this research, which is to categorise the dimensions of the quality of public universities as perceived by stakeholders, the conclusions are:

- From the aspect of distributing individual indicators in policy documents, the results revealed a poor focus on the balance of input, process and output indicators.

- Each of the analysed strategic documents and documents relevant to the allocation of financial resources to public universities encompasses the process evaluation with more than $50 \%$.

- The shift towards output-based education, which aims are contained in policy documents and legal solutions, is not adequately reflected through indicators. 
DRUŠ. ISTRAŽ. ZAGREB

GOD. 28 (2019), BR. 2, STR. 333-352

PETRUŠIĆ, I.: LOST IN THE PROCESS..
- Although some current research (Udam \& Heidmets, 2013) reveals that different parties' interpretations and expectations for higher education quality differ significantly, this analysis in the Croatian context shows that when measuring the quality of higher education institutions, all stakeholders rely on the evaluation of the process quality as the percentage of indicators that is most significant to almost all tools aimed at measuring the quality of public universities for different purposes.

- According to the importance of indicators, teacher and student mobility are categories that are evaluated in the documents of all stakeholders. Strategic plans and their elaboration are also of the highest importance (4.33), as well as some of the input indicators (number and qualifications of researchers and terms of enrolment in the higher education institution). The output indicators of high importance are the employability rate of graduate students (4.33), the number of scientific publications (4.33), learning outcomes of graduate students (4.00) and transfer of technology (4.00).

- Most of the process performance indicators are related to the quality of student experience and tracking their progress (i.e. student support, teaching and research monitoring mechanisms, procedures for monitoring the quality of study programmes, physical resources and teaching aids, etc.).

The results of this study show similarities in how major stakeholders - government, academia and agencies evaluate and perceive quality. The focus on certain performance segments of public universities through process indicators is likely to have its starting point regarding its effectiveness - the availability and ease of use of the data required to show more quality in those instances. By evaluating the quality of public universities through processes, the results of these interventions are very quickly and clearly visible, as well as their short-term impact - a shift in quality improvement. However, while indirectly affecting processes in public universities, such procedures also affect the perception of their own quality.

An overview of the quality of public universities through the quality of procedures and processes is also present in the European quality assurance framework (ENQA, 2015). However, considering the quality of public universities, there is a possibility that the quality assurance system focuses on bureaucratic document management and management issues rather than the actual impact on the quality of public universities and, consequently, the quality of the entire system.

Finally, all stakeholders involved in the external evaluations of public universities should put more effort into defining quality and quality evaluation at the national level and its 
DRUŠ. ISTRAŽ. ZAGREB GOD. 28 (2019), BR. 2, STR. 333-352

PETRUŠIĆ, I.: LOST IN THE PROCESS.. compatibility with international perspectives. In order to promote visibility of Croatian higher education institutions, the output indicators of these inputs, processes and research quality should certainly be more intensively concentrated (in terms of number and weighted average) in the quality assessment systems that will be implemented through the evaluations of public universities.

\section{NOTES}

${ }^{1}$ Number of students by HEI and study type https://www.azvo.hr/ hr/visoko-obrazovanje/statistike/44-statistike/690-ukupan-brojstudenata-po-tipu-visokih-uilita-za-0910-i-1011 (access 9/10/2017)

2 http://www.unios.hr/kvaliteta/wp-content/uploads/sites/2/2016/03/ Prirucnik-kvalitete-3.0.pdf

${ }^{3}$ https://www.unipu.hr/uploads/media/PK_2013.pdf

${ }^{4}$ http://www.unidu.hr/datoteke/19izb/Prirucnik_kvalitete_-2012-05-02.pdf

${ }^{5}$ https://www.uniri.hr/files/kvaliteta/dokumenti/Prirucnik_za_kvalitetu_ 2016.pdf

${ }^{6}$ http://more.unist.hr/Portals/7/docs/Prirucnik osiguravanja kvalitete - UNIST.pdf

${ }^{7}$ http://www.unizd.hr/Portals/0/kvaliteta/Prirucnik_kvalitete.pdf

8 http://www.unizg.hr/fileadmin/rektorat/Studiji_studiranje/Studiji/ Kvaliteta/Kvaliteta2/anketa/Prirucnik-osiguravanje-kvalitete-tisak02-2014.pdf

\section{REFERENCES}

ASHE (2010). Criteria for the quality of higher education institutions within universities. Agency for Science and Higher Education, Zageb. Available at https://www.azvo.hr

ASHE (2013). Principles and criteria for the evaluation of scientific organisations in the Republic of Croatia. Agency for Science and Higher Education, Zagreb. Available at https://www.azvo.hr,

ASHE (2015). Reaccreditation of postgraduate university study programmes in Croatia: Principles and criteria reaccreditation of postgraduate university study programmes in Croatia: Principles and criteria. Agency for Science and Higher Education, Zagreb. Available at https://www. azvo.hr

Beerkens, M. (2015). Quality assurance in the political context: In the midst of different expectations and conflicting goals. Quality in Higher Education, 21(3), 231-250. https://doi.org/10.1080/13538322.2015. 1111004

Blanco-Ramírez, G., \& Berger, J. B. (2014). Rankings, accreditation, and the international quest for quality: Organizing an approach to value in higher education. Quality Assurance in Education, 22(1), 88-104. https://doi.org/10.1108/QAE-07-2013-0031 
DRUŠ. ISTRAŽ. ZAGREB GOD. 28 (2019), BR. 2, STR. 333-352

PETRUŠIĆ, I.: LOST IN THE PROCESS..
Bowen, G. A. (2006). Document analysis as a qualitative research method. Qualitative Research Journal, 9(2), 27-40. https://doi.org/10.3316/ QRJ0902027

Chalmers, D. (2008). Teaching and learning quality indicators in Australian universities. In Outcomes of Higher Education: Quality relevance and Impact. Organisation for Economic Co-operation and Development (OECD).

Choy, S., \& Lidstone, J. (2011). Grading: Harmonising standards and stakeholder expectations. Quality in Higher Education, 17(1), 111-115 https://doi.org/10.1080/13538322.2011.554635

Clark, B. R. (1983). The higher education system: Academic organization in cross-national perspective. Berkeley: University of California Press.

Cohen, L., Manion, L., \& Morrison, K. (2007). Research methods in education (6th, Ed.). London and New York: Routledge. https://doi. org/10.1111/j.1467-8527.2007.00388_4.x

CP (2014). The Strategy for education, science and technology. Croatian Parliament, Zagreb, OG 124/2014.

de Sousa Santos, B. (2006). The university in the 21st century: Toward a democratic and emancipatory university reform. In I. R. A. R. \& C. A. Torres (Eds.), The university, state, and market (pp. 60-100). Stanford, CA: Stanford University Press.

Elo, S. \& Kyngäs, H. (2008). The qualitative content analysis process. Journal of Advanced Nursing, 62(1), 107-115.

ENQA (2015). Standards and Guidelines for quality assurance in the European higher education area (ESG). Available at http://www.enqa. eu/wp-content/uploads/2015/11/ESG_2015.pdf

Filippakou, O. (2011). The idea of quality in higher education: A conceptual approach. Discourse. Studies in the Cultural Politics of Education, 32(1), 15-28. https://doi.org/10.1080/01596306.2011.537068

Ghurchian, N. G., Jafari, P., \& Rahgozar, H. (2010). Designing a model for performance evaluation in Iranian universities based on the organizational excellence indicators. European Journal of Social Sciences, 17(3), 434-441.

Harvey, L. (2006). Understanding quality, Section B 4.1-1 of 'Introducing Bologna objectives and tools'. In L. Purser (Ed.), EUA Bologna handbook: Making Bologna work. Brussels European University Association and Berlin, Raabe. https://doi.org/10.1016/B978-0-7506-57419.50004-4

Harvey, L., \& Green, D. D. (1993). Defining quality. Assessment $\mathcal{E}$ Evaluation in Higher Education, 18(1), 9-34. https://doi.org/10.1080/026 0293930180102

Harvey, L., \& Newton, J. (2004). Transforming quality evaluation. Quality in Higher Education, 10(2), 149-165. https://doi.org/10.1080/135 3832042000230635

Killen, R. (2000). Outcomes-based education: Principles and possibilities. Unpublished manuscript, University of Newcastle, Faculty of Education. https://doi.org/10.1111/j.1365-2929.2005.02210.x 
DRUŠ. ISTRAŽ. ZAGREB GOD. 28 (2019), BR. 2, STR. 333-352

PETRUŠIĆ, I.: LOST IN THE PROCESS..
Maguire, K., \& Gibbs, P. (2013). Exploring the notion of quality in quality higher education assessment in a collaborative future. Quality in Higher Education, 19(1), 41-55. https://doi.org/10.1080/13538322. 2013.774220

MSE (2010a). Ordinance on the content of license and conditions for issuing license for performing higher education activity, carrying out a Study Programme and Re-accreditation of Higher Education Institutions, OG 24/2010.

MSE (2010b). Ordinance on conditions for issuing license for scientific activity, conditions for re-accreditation of scientific organizations and content of license. Government of the Republic of Croatia, OG 69/2013.

MSE (2012). Decisions on grants for study costs for full-time first-year students at public higher education institutions in the Republic of Croatia. Ministry of Science and Education, Zagreb. http://public.mzos.hr/ Default.aspx?sec $=3329$ (retrieved June 1, 2018).

MSE (2013). Multi-annual institutional funding of scientific activities at public universities and research institutions in 2013, 2014 and 2015. Ministry of Science and Education, Zagreb. https://mzo.hr/hr/rubrike/ namjensko-visegodisnje-institucijsko-financiranje-znanstvenedjelatnosti (retrieved July 9, 2018).

NSC (2007). Ordinance on the conditions of academic appointment. National scientific council, Croatian Parliament, Zagreb, OG 120/2007.

Rosa, M. J., \& Amaral, A. (2007). A self-assessment of higher education institutions from the perspective of the EFQM excellence model. In D. F. Westerheijden, B. Stensaker, \& M. J. Rosa (Eds.), Quality assurance in higher education. Higher Education Dynamics, Vol. 20. Dordrecht: Springer. https://doi.org/10.1007/978-1-4020-6012-0_7

Santiago, R., \& Carvalho, T. (2012). Managerialism rhetorics in Portuguese higher education. Minerva, 50(4), 511-532. https://doi.org/10. 1007/s11024-012-9211-9

Stensaker, B., \& Leiber, T. (2015). Assessing the organisational impact of external quality assurance: Hypothesising key dimensions and mechanisms. Quality in Higher Education, 21(3), 328-342. https://doi. org/10.1080/13538322.2015.1111009

Tavares, O., Sin, C., Videira, P., \& Amaral, A. (2016). Academics' perceptions of the impact of internal quality assurance on teaching and learning. Assessment and Evaluation in Higher Education, 42(8), 1293-1305. https://doi.org/10.1080/02602938.2016.1262326

Tight, M. (2013). Discipline and methodology in higher education research. Higher Education Research and Development, 32(1), 136-151. https://doi.org/10.1080/07294360.2012.750275

Udam, M., \& Heidmets, M. (2013). Conflicting views on quality: Interpretations of "a good university" by representatives of the state, the market and academia. Quality in Higher Education, 19(2), 210-224. https://doi.org/10.1080/13538322.2013.774805

Urbanovič, J., \& Wilkins, S. (2013). Internationalisation as a strategy to improve the quality of higher education in small states: Stakeholder perspectives in Lithuania. Higher Education Policy, 26(3), 373-396. https://doi.org/10.1057/hep.2013.6 
DRUŠ. ISTRAŽ. ZAGREB GOD. 28 (2019), BR. 2, STR. 333-352

PETRUŠIĆ, I.: LOST IN THE PROCESS..
Van Damme, D., Van Der Hijden, P., \& Campbell, C. (2004). Quality and recognition in higher education. Quality and recognition in higher education: The cross-border challenge. Organisation for Economic Co-operation and Development (OECD). https://doi.org/10.1787/9789264015104-en Van Kemenade, E., Pupius, M., \& Hardjono, T. W. (2008). More value to defining quality. Quality in Higher Education, 14(2), 175-185. https:// doi.org/10.1080/13538320802278461

Van Vught, F. A., \& Westerheijden, D. F. (1994). Towards a general model of quality assessment in higher education. Higher Education, 28(3), 355-371. https://doi.org/10.1007/BF01383722

\section{Izgubljeni u procesu: Kako dionici percipiraju kvalitetu javnih sveučilišta u Hrvatskoj?}

\author{
Irena PETRUŠIĆ \\ Agencija za znanost i visoko obrazovanje, Zagreb
}

Obrazovanje temeljeno na ishodima postaje relevantan diskurs u procjeni kvalitete studijskih programa kroz politiku Europske komisije. Analizom pokazatelja vrednovanja koji upućuju na željeni koncept kvalitete ovo istraživanje pruža uvid u očekivanja koja glavni dionici (država, akademske zajednice i agencije) $u$ hrvatskom visokom obrazovanju imaju od javnih sveučilišta i jesu li ta vrednovanja upravljena prema učincima, što je navedeno kao cili u europskom, ali i u hrvatskom, kontekstu. Percepcija kvalitete koju dionici podrazumijevaju vrednovanjem javnih sveučilišta za razne svrhe analiziraju se uz pomoć karakteristika pokazatelja kroz matricu input-process-output. Rezultati pokazuju kako se kvaliteta uvelike temelii na mjerenju kvalitete procesa na visokoškolskim ustanovama, zatim inputima i samo u manjoi mjeri outputima. Prema važnosti pokazatelja, mobilnost nastavnika i studenata jesu kategorije zastupljene u dokumentima svih dionika. U konačnici, ovaj rad uključuje doprinos razmatranju i vrednovanju kvalitete javnih sveučilišta na nacionalnoj razini i njihovu kompatibilnost $s$ međunarodnim perspektivama.

Ključne riječi: akademska kvaliteta, javno sveučilište, input-process-output matrica

\section{(c) (i) (8)}

Međunarodna licenca / International License:

Imenovanje-Nekomercijalno/ Attribution-NonCommercial 